\title{
The historical evolution of female earnings functions and occupations
}

\section{Citation}

Goldin, Claudia. 1984. "The Historical Evolution of Female Earnings Functions and Occupations." Explorations in Economic History 21 (1) (January): 1-27. doi:10.1016/0014-4983(84)90014-7.

\section{Published Version}

doi:10.1016/0014-4983(84)90014-7

\section{Permanent link}

http://nrs.harvard.edu/urn-3:HUL.InstRepos:30703975

\section{Terms of Use}

This article was downloaded from Harvard University's DASH repository, and is made available under the terms and conditions applicable to Other Posted Material, as set forth at http:// nrs.harvard.edu/urn-3:HUL.InstRepos:dash.current.terms-of-use\#LAA

\section{Share Your Story}

The Harvard community has made this article openly available.

Please share how this access benefits you. Submit a story.

\section{Accessibility}


NBER WORKING PAPER SERIES

THE HISTORICAL EVOLUTION OF FEMALE

EARNINGS FUNC'TIONS AND OCCUPATIONS

Claudia Goldin

Working Paper No. $\underline{529}$

NATIONAL BUREAU OF ECONOMIC RESEARCH 1050 Massachusetts Avenue

Cambridge MA 02138.

August 1980

This research has been supported by NSF Grant \#SOC 78-15037. The author is grateful to Stanley Engerman and to Paul Taubman for their comments and to the National Archives staff for cooperating in the sampling of the women's Bureau schedules. Please do not quote or cite without the author's permission. The research reported here is part of the NBER's research program in the Development of the American Econond. Any opinions expressed are those of the author and not those of the National Bureau of Economic Research. 
The Historical Evolution of Female

Earnings Functions and Occupations

\section{ABSTRACT}

Of all the changes in the history of women's market work, few have been more impressive than the rapid emergence and feminization of the clerical sector and the related decline in manufacturing employment for women. Although a century ago few women were clerical workers, as early as $192022 \%$ of all employed nonfarm women were, and about $50 \%$ of all clerical workers were women. Employment for women in the clerical sector expanded at five times the annual rate in manufacturing from 1890 to 1930 , and during the same period of time wages for female clerical workers fell relative to those in manufacturing. This paper explores the underlying causes of these dramatic sectoral shifts by estimating the relationship between earnings and experience for manufacturing and clerical workers from 1888 to 1940 . It is seen that earnings profiles for employment in manufacturing rose steeply with experience and peaked early, while those in the clerical sector were much flatter and did not peak within the relevant range. Returns to off-job training and depreciation with age and with time away from the labor force also differed between these occupations. A model of sectoral shift is developed in which workers choose occupations and therefore the time path of training on the basis of their life-cycle labor force participation and their consumption value of education. The coefficients from the earnings function estimations are used to demonstrate that the decline in the relative wage of clerical to manufacturing work from 1890 to 1930 can be explained by such a model. Finally, it is shown that a sizable percentage of the difference in the growth of female employment in the manufacturing and clerical sectors can be explained by various labor supply factors.

Claudia Goldin

Department of Economics

University of Pennsylvania

3718 Locust Walk, CR

Philadelphia, PA 19104

215-243-7733/609-921-8716 
The structure of occupations for women has undergone episodic changes throughout history. Despite frequent claims that the recent transformation in women's work is an unheralded phenomenon, it is in fact a small part of a more expansive historical evolution in the structure of occupations. Of all the changes witnessed in the history of this labor market, few have been more impressive than the rapid emergence and feminization of the clerical sector and the related decline in manufacturing employment for women. A century ago clerical sector employment for women was practically non-existent, yet clerical work has been the quintessential female occupation for most of the twentieth century. This transformation was so rapid that even as early as $1920,22 \%$ of all employed non-farm women in the U.S. were clerical workers and about $50 \%$ of all clerical workers were women. Change in the composition of the female work force, from young and single to older and married women, was less rapid. But this slow demographic evolution appears to have been related to the more dramatic structural transformation of jobs. This paper will explore the underlying causes of both the sectoral shift in occupations and the related compositional change of the female labor force.

Work in manufacturing and clerical employment offered two distinct earnings-experience profiles. Most important among these differences was the entrance requirement of some off-job training in the clerical sector. Not surprisingly, wages were higher for clerical work than for that in manufacturing, but for the families of most young women with limited job attachment, manufacturing work was still preferable. Various changes during the early twentieth century, most prominently the rise of high school education, drew young women in large numbers from the manufacturing 
to the clerical sector. The relative wage of clerical work to that in manufacturing fell substantially during this period. The differential growth in female employment in these two sectors was impressive; the average annual increase in the clerical sector was almost five times that in manufacturing. Changes in the structure of the economy, primarily increases in the service sector, served to buoy the demand for office workers. But individual choice of occupations by young women and their families may have accounted for a large fraction of the differential growth of employment in the manufacturing and clerical sectors.

The model developed to explain these historical changes summarizes an occupation by the vector of characteristics associated with its earningsexperience profile. Occupations may differ by off-job and on-the-job training and by the depreciation of skills with age and with time away from the labor market. Individuals with differing life-cycle labor force participation may opt for different occupations, and many have viewed the segregation of occupations by sex as a product of such individual optimization [Mincer and Polachek, 1974; Polachek, 1979; Zellner, 1975]. 1 / The properties of earnings functions for contemporary women have been explained by the duration and intermittancy of their work experience. Their earnings rise slowly with experience on-the-job and there is little depreciation of skills with age and with time away from work. Particular occupations therefore have attracted women who expect to exit and reenter the labor force at a later date, with the result that women have generally become nurses and not doctors, typists and not executives. But relatively flat earnings profiles, suggesting little on-the-job training, have not always been the distinguishing feature of female 
occupations. It was only with the emergence of the clerical sector early in this century that women were able to choose an occupation with these characteristics. The dominant work for women at that time, other than domestic service, was that in manufacturing, and the features of its earnings profile were wholly dissimilar to those we now view as customary for women.

This paper has two purposes. The first is to demonstrate that relatively flat earnings profiles have not always been the norm for women's occupations and that the choice of occupations by characteristics of the earnings profile can be viewed as part of a long and continuous process in American history. The second is to use estimates of the earnings profiles to judge whether changes in relative wages in the two sectors from 1890 to 1930 could have resulted from particular supply side influences. The impact of these influences on the relative growth of female employment in the two sectors can then be assessed.

The first section describes the features of female earnings profiles estimated for various samples of manufacturing and clerical workers from 1888 to 1940. It is highly fortunate that these surveys, which contain data as rich as those in more recent studies, have survived. Earnings profiles for employment in manufacturing in 1888 and in 1907 rose steeply with experience and peaked early, while those in the clerical sector at a later period were much flatter and did not peak within the relevant range. There were, as well, other features of these profiles that differed, giving young women a choice as to which characteristics they valued more highly at given wages. The second section discusses changes in the occupational structure of female employment and in the composition of the female labor force from 
1890 to 1950. The timing of changes in both areas is stressed, in particular the fact that the rise of clerical work for single women, beginning with the large gains during 1900 to 1920, preceded the increase in clerical employment for married women, which expanded continuously from 1920. The third section develops a model of sectoral shift in which labor supply variables are stressed. Workers choose occupations, and therefore off-job and on-job training, on the basis of the earnings profile of the occupation and their expected lifetime labor force participation. It is shown that the decline in the relative wage rate of female clerical workers can be rationalized within this context and that a sizable percentage of the difference in the growth of female employment in the manufacturing and clerical sectors can be explained by various labor supply factors.

\section{Earnings Functions for Women, 1888 to 1940}

During the two decades around the turn of this century most working women were single, and those who were married and in the labor force were generally not career women, but were instead working to overcome some unanticipated loss in income from a husband's illness or unemployment. A substantial fraction of single women who worked when young expected therefore to leave the labor force upon marriage and not to reenter it.

There were two major occupational groups for women in the late nineteenth century: factory work and domestic service. Employment for young women in manufacturing increased in importance during the late nineteenth century, comprising $24.6 \%$ of all non-farm working women in 1870 but $31.8 \%$ in 1890. The major industries employing women were textiles, clothing, food, shoes, paper, and tobacco. More important than the nature of the industries 
that employed them was the pervasive organization of work for women in manufacturing. About $47 \%$ of women across all industries worked on piece rates in 1890, and it will be seen that this method of renumeration is critical in understanding the structure of earnings with experience. 2 / Occupations varied greatly within the manufacturing sector, but characteristics were common to virtually all positions in terms of the education and training required for the job, and the dexterity and physical acumen demanded of the worker. Various social concerns during the Progressive Era led to the collection of data on the earnings, individual characteristics, and family lives of working women. Data from two surveys, Working Women in Large Cities (hereafter the 1888 Study) and Woman and Child Wage Earners (the 1907 Study) have been used in this paper to estimate the determinants of earnings, particularly the relationship among earnings, experience on-the-job, and schooling.

The 1888 Study was highly comprehensive, including information on earnings, job experience, and other personal and family characteristics for 1107 city-industry cells. Women of all marital states were included, with single women comprising $88 \%$ of the total. The 1907 Study contains similar information for single and married women separately across five industries. This paper uses data from two industries, cotton textiles and men's clothing, and the sample for single women consists of 2436 individual observations and that for married women of 937 observations.

Earnings equations were estimated for both studies of the form implied by a linearly declining investment ratio [Mincer, 1974],

$$
\log Y_{t}=\beta_{0}+\beta_{1} e_{t}+\beta_{2} e_{t}^{2}+\beta_{3} s+\beta_{4} D+\sum_{i} \alpha_{i} x_{i}+v
$$

where $\log Y_{t}=\log$ of annual earnings at time $t, e_{t}=$ years at work at time $t$, 
$\mathrm{s}=$ years at school, $\mathrm{D}=$ days lost or days worked per year, and the $\mathrm{x}_{i}{ }^{\prime} \mathrm{s}$ are personal and family characteristics that influence the efficiency or intensity of market work. It should be noted at the outset that the main results of this paper are independent of this particular functional form, and that a highly flexible form yielded essentially the same results. In addition, although "synthetic cohort" forms are estimated, which might be flatter than actual earnings functions, the conclusions from comparisons across occupations are probably not affected. The definitions of the variables vary somewhat across the two samples and are given in Table 1 . The regression results are given in Table 2 .

Earnings rose steeply with experience on-the-job and peaked early in both samples. Most of the young women in the two samples entered work around age 15, and their earnings peaked or plateaued about 15 years later, using the total job experience measure for 1907. The earnings function for the 1888 Study peaks even earlier, because experience here is measured by years at a particular job and not by total experience. When total experience (that is, age minus age at which work began) is substituted, the earnings profile is virtually identical to that estimated for 1907. By the time the earnings function had plateaued or peaked, a large fraction of these young women had married and had exited from the labor force.

Education, which is given in the 1907 Study as months of school attended, is converted here to a 9 month school year. It increased earnings an average of $2 \%$ per year, with returns peaking at about 96 months of schooling or at about 10 school years. 4 / These gains from education appear to be attributable mainly to literacy, which by itself served to increase earnings by about $14 \%$ - Work in manufacturing therefore involved substantial learning on-the-job, and there appears to have been relatively little possibility for the substitution of off-job preparation. 
TABLE 1

VARIABLE DEFINITIONS AND SAMPLE MEANS FOR TABLES 2 AND 3

A. Manufacturing Samples:

1888 Study

Log annual earnings = dependent variable $\quad 5.52$

$\begin{array}{ll}\text { Experience * years in present occupation } & 4.37\end{array}$

School = age minus Experience minus 7
Days lost = days per year not working, generally due to shop closings

\begin{tabular}{ll} 
& 0.04 \\
\hline
\end{tabular}

$\begin{array}{lr}* \text { widowed } & 0.07 \\ \end{array}$

Health = in bad health $\quad 0.03$

1907 Study, Single Women

Log annual earnings * dependent variable 5.31

$\begin{array}{ll}\text { Experience }=\text { age minus age at which work began } & 4.40\end{array}$

School = schooling defined as [months attended school/9] 4.86

Days worked = days employed per year 222

Age began work $\quad 14.0$

1907 Study, Married and Widowed Women

Log annual earnings $=$ dependent variable 4.83

$\begin{array}{ll}\text { Age } & 35.46\end{array}$

Work at home = Dummy $=1$, if woman works for pay in her home 0.57

Days worked = days employed per year 191

Widow = Dumn $=1$, if husband is dead 19.14

thusb. idle $=$ Dummy $=1$, if husband is unemployed or sick 0.04

$\begin{array}{ll}\text { Husb. absent }=\text { Dummy }=1, \text { if husband is absent. } & 0.04\end{array}$

B. Clerical Sample: 1940 Study

Log full time earnings = dependent variable $\quad 6.98$

Experience $=$ years experience with current firm $\quad 8.29$

Continuous = Dumby $=1$, if experience with this firm has been continuous 0.89

Grade Schl = years in grade school with this firm has been continuous 7.99

H.S. = years in high school $\quad 3.01$

Comm Crs. = Dummy $=1$, if a comaercial course was taken in high school $\quad 0.14$

Bus Schl = years in business school $\quad 0.33$

$\begin{array}{lr}\text { College }=\text { Dumy }=1, \text { if graduated from college } & 0.05\end{array}$

$\begin{array}{ll}\text { Voc } S c h l=\text { years in vocational school } & 0.02\end{array}$

$\begin{array}{ll}\text { Years at Home = years since began all office work minus Experience, } & \\ \text { minus years at other office work } & 0.52\end{array}$

Years Laid off = years laid off from this firm $\quad 0.15$

$\begin{array}{ll}\text { \& married } & 0.23\end{array}$

$\begin{array}{ll}\text { 7 single } & 0.74\end{array}$

Years experience in other office jobs $\quad 2.60$

$\begin{array}{lr}\text { Age } & 30.40\end{array}$

NOTE: Because these are means from the working population, they do not necessarily reflect the means for an individual experience. For example, the 1907 Study. Single Women sample contains large numbers of very young women and therefore the mean years of work experience for an individual would be higher than the sample mean. A similar, but wore complicated, problem exists in computing the mean age at entering work.

SOURCES: See text. 
TABLE 2

EARNINGS FUNCTIONS FOR WOMEN IN MANUFACTURING: 1888, 1907

A. Single Women

Dependent variable $=$ log annual earnings

1888 Study

Constant

$4.816^{*}$

(0.121)

Experience

$0.088^{*}$

$(0.009)$

$\operatorname{Exp}^{2} \times 10^{-2} \quad-0.463^{\text {* }}$

$(0.067)$

School

$$
0.151^{*}
$$$$
(0.026)
$$

$\mathrm{Sch}^{2} \times 10^{-2}$

$-0.650^{*}$

(0.148)

$\%$ Married

$-0.262^{*}$

$(0.095)$

$\%$ Widowed

$-0.381^{*}$

(0.108)

Log Days Lost $\quad-0.089^{*}$

(0.011)

Health

$-0.287^{\text {* }}$

$(0.126)$
1907 Study

Constant

$-1.860^{*}$

Experience

0.094 *

$(0.004)$

$\operatorname{Exp}^{2} \times 10^{-2}$

$-0.285^{*}$

(0.016)

School

$0.038^{\text {* }}$

$(0.008)$

$\operatorname{Sch}^{2} \times 10^{-2}$

$-0.176^{*}$

$(0.079)$

Log Days Worked

$1.199^{*}$

$(0.016)$

Age Began Work

$0.022^{*}$

$(0.003)$

Number of

Observations

$\mathrm{R}^{2}$

0.995

$(0.325)^{a}$

0.805

\section{Notes}

1888 - All variables weighted by $\sqrt{n}$, where $n=$ number of women in each industry-city category. Other variables entered: regional dummies (omitted dummy $=$ Midwest), and a proxy for experience in other jobs.

1907 - Other variables entered: state or city dummies (omitted dummy = New York), presence of parents in home.

Standard errors are in parentheses under coefficients. Ali starred coefficents $\left(^{*}\right)$ are significant at the $5 \%$ level; those with $\left({ }^{* *}\right)$ are significant at the $10 \%$ level.

Variable definitions and means are in Table 1. 
B. Married Women: 1907 Study

Dependent variable $=\log$ annual earnings

$\begin{array}{lc}\text { Constant } & -0.391^{\star} \\ \text { Age } & 0.016^{\star \star} \\ & (0.009) \\ \text { Age }^{2} \times 10^{-2} & -0.031^{\star} \\ & (0.012) \\ \text { Works at Home } & -0.487^{*} \\ & (0.042) \\ \text { Log Days Worked } & 1.065^{\star} \\ & (0.027) \\ \text { Widow } & 0.055 \\ \text { Husb. Idle } & (0.058) \\ & 0.151{ }^{\star *} \\ \text { Husb. Absent } & (0.080) \\ \text { Number of Observations } & -0.014 \\ \mathrm{R}^{2} & (0.082) \\ \end{array}$

Notes: Other variables entered: state or city dummies, number and ages of children, and nativity. Age, not job experience, was used in this regression because job experience was not given for married women.

$a_{\text {The }} \mathrm{R}^{2}$ in parentheses applies the coefficients from this GLS estimation to the unweighted data. 
Four major factors account for the shape of the manufacturing earnings function: maturity, on-the-job training, and depreciation from aging and job related factors. A small part of the steeply rising initial section is accounted for by maturity alone. Because the 1907 Study contains data on age, years at school, and the age at which work began, maturity can be separated from learning on-the-job by entering the age at which work began in addition to job experience. Earnings would have risen at $2.2 \%$ per year, around the age of entering the labor force, even without job training. Therefore, the steeply rising segment which remains after accounting for relative maturity is a function of job related factors alone.

Because almost one-half of women working in manufacturing in 1890 were paid by the piece, the rising portion of the earnings profile is not merely a construct of a labor market with substantial hiring or firm specific training costs. [See, for example, Salop and Salop 1976, for an elaboration of the relationship between job screening and earnings functions.] This portion of the profile is, instead, a function of the increased proficiency of workers with more job experience. In some industries, increased proficiency implied job advancement; for example, in clothing manufacture young women would advance from being basting pullers, to being sewers, to skilled basters and button-hole sewers. In other industries, increased proficiency meant that the worker produced more and better output; for example in weaving a more experiencedworker would tend more looms and produce fewer defective pieces. But increases in proficiency during the early years of work did not necessarily imply job advancement throughout working life. Although the earnings profile for young men in manufacturing in 1907 was less steeply rising than that for young women, rather than plateauing early it continued to rise. 6 Job learning for women in manufacturing may have been substantial at first, but in most industries, proficiency and therefore earnings were inevitably limited by the job itself。? 
Therefore another important feature of the earnings profile for single women was its early peaking and decline or possible plateauing. 8 - Data for married women from the 1907 Study indicate a similar but moderate decline in earning capacity with age. (The 1907 data for married women do not give years of job experience and therefore age was included instead.) Earnings were reduced by about $1 \%$ per year from the late thirties to the early fifties and about $2 \%$ per year from age 55 (Table 2, Part B). Many of these women were sewers, working in their homes and using skills that had depreciated less with time out of the labor force than with age. $9 /$ These data suggest that the finding for single women of a peak in the earnings experience profile is not an artifact either of the small sample size both at older ages and at higher experience levels or of some selective sampling bias. Although some of the decline in earnings may have been a product of aging alone, another part may have been caused by physical depreciation from job related factors particularly for those working in factories. 10 f Earnings functions for men working in the manufacturing and mining sectors at the same time period also peaked earlier than do those for contemporary men, but these earnings profiles for men did not peak as early as did those for turn-of-the-century women. Because of data limitations, it is difficult to compute the impact on earnings of intermittant labor force participation for women in these samples. The fact that married and widowed women earned $26 \%$ and $38 \%$ less, respectively, than did single women in 1888 suggests a decrease in earnings with time away from the labor force, but age itself may have been the overriding factor in this regard.

In 1907 there were a half million female clerical workers, less than a third the number of women employed in manufacturing. But by 1925 female employment in the two sectors was about equal, and governmental agencies began to divert some of their attention from the conditions of work in the factory 
to various aspects of work in offices. Comprehensive surveys of female clerical workers were taken by the Women's Bureau of the Department of Labor, the first in 1930 and another in 1940, which also included comparable data for men. Various studies by states and by the National Industrial Conference Board were also made during this period, but these were primarily surveys of firms and not of individual workers. Summary reports of the two Women's Bureau studies can be found in the bulletins of the Bureau, but the data contained in these reports are highly aggregated. Although the original schedules for the 1930 study appear to have been destroyed, I have located those for the 1940 survey in the National Archives, D.C. The schedules for Philadelphia have been sampled, yielding 724 observations for females and 482 for males.11/ These data contain detailed micro-level information on work histories, education, personal characteristics, and earnings both in 1939 and at the beginning of office work. These data have been used to estimate equation (1), and the results are given in Table 3. Sample means and variable definitions are given in Table 1.

In contrast to the earnings function in manufacturing, that for female clerical workers is considerably less peaked. It is flatter during the early period of employment and increases throughout the relevant labor force experience range, rising at about $3.4 \%$ on average per year. Data from the earlier, 1930, Women's Bureau survey of clerical workers, for which only aggregate returns exist, exhibit similar relationships between earnings, experience, and schooling. $\frac{12 /}{}$ It will be assumed, therefore, for the empirical specification in Section 3 that the characteristics of the earnings profile for clerical workers estimated with the 1940 data can be applied to a period somewhat earlier. 
The return to grade school education for clerical workers was about equal to that in the manufacturing sample, but the returns to high school education were greater. $\frac{13 /}{}$ Furthermore, vocational school, business training, and college substantially increased earnings for clerical workers, and a high school diploma, of course, was generally a prerequisite for such education.

Unlike the manufacturing sample, the clerical survey allows a direct computation of skill depreciation from years away from work due either to "home time" or to being laid off the job. Each year of "home time" resulted in a $1.8 \%$ decline in earnings, a figure of comparable magnitude to that estimated for contemporary profiles. $14 /$ The "home time" coefficient is slightly less than the $2.2 \%$ decline due to furloughs, which is reasonable since being laid off the job may signal lower job productivity. The inclusion of age as a variable in the Table 3 regression does not result in a significant coefficient. Therefore, decreases in productivity in clerical work arose from gaps in labor force participation and not from depreciation in job skills because of aging.

In summary, the essential differences between the earnings function for manufacturing work and for clerical work concern the returns to higher and vocational education, the possibility of learning on-the-job, and the roles of age and job related depreciation in affecting earnings. All of these factors were important in the decisions of young women and their families regarding schooling and occupational choice during the early part of this century. I will assume in the remainder of this paper that the choice of occupations is coincident with the choice between the features of the two earnings profiles and that young women and/or their parents made decisions by maximizing the present discounted value of net earnings. 
TABLE 3

EARNINGS FUNCTIONS FOR WOMEN IN CLERICAL WORK: 1940

$\underline{\text { Dependent }}$ variable $=$ "full-time" annual earnings ${ }^{a}$

\begin{tabular}{|c|c|}
\hline Constant & $5.971 *$ \\
\hline Experience & $\begin{array}{c}0.035^{*} \\
(0.003)\end{array}$ \\
\hline $\operatorname{Exp}^{2} \times 10^{-2}$ & $\begin{array}{l}-0.024^{*} \\
(0.010)\end{array}$ \\
\hline Continuous & $\begin{array}{l}0.136{ }^{*} \\
(0.030)\end{array}$ \\
\hline Grade Schl, yrs. & $\begin{array}{c}0.042 \\
(0.027)\end{array}$ \\
\hline H.S., yrs. & $\begin{array}{l}0.022^{*} \\
(0.012)\end{array}$ \\
\hline Comm Crs & $\begin{array}{c}0.042 \\
(0.047)\end{array}$ \\
\hline Bus Schl, yrs. & $\begin{array}{c}0.047^{*} \\
(0.017)\end{array}$ \\
\hline College, grad. & $\begin{array}{l}0.173^{*} \\
(0.062)\end{array}$ \\
\hline Voc Sch 1 , yrs. & $\begin{array}{c}0.111^{*} \\
(0.050)\end{array}$ \\
\hline Years at Home & $\begin{array}{l}-0.018^{*} \\
(0.005)\end{array}$ \\
\hline Years Laid off & $\begin{array}{l}-0.022^{*} \\
(0.010)\end{array}$ \\
\hline Number of Observations & 724 \\
\hline $\mathrm{R}^{2}$ & 0.48 \\
\hline s.e.e. & 0.23 \\
\hline
\end{tabular}

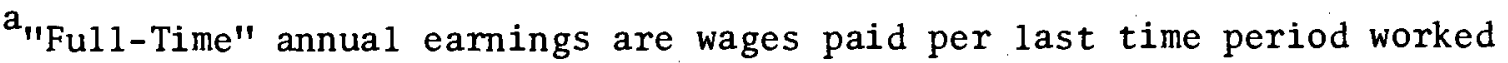
multiplied by the number of time periods per year, i.e. weekly earnings were multiplied by 52 , monthly earnings by 12 , and so on. Women in clerical work were generally paid by the week.

Notes: Other variables entered: marital status, experience in other offices, and other measures of education and vocational training. (*) Significant at the $5 \%$ level; $\left({ }^{* *}\right)$ significant at the $10 \%$ level. 
One can explain a large part of both the decline in the relative wage rate of clerical to manufacturing work and the differential rate of growth in employment in the two sectors over the period 1890 and 1930 by considering changes in labor supply factors relating to the earnings profiles of the two occupations. Employment of women in the clerical sector rose as single women decided that they might remain in or reenter the labor force after marriage. Employment in the clerical sector was also influenced by changes in the valuation by parents of their daughters' time in school and at home. Rising incomes led parents to purchase more schooling and leisure for their children and to reduce the supply of young workers to manufacturing jobs. A more precise model of the impact of such changes is developed and applied in Section 3. A short history of female employment and wages in the U.S. is presented in Section 2 to demonstrate that changes in employment between these two sectors is of critical importance in the evolution of the labor market for women.

\section{Employment of Women and Female Wages, 1890 to 1950}

In 1890 only $11 \%$ of the non-farm female labor force was married but by 1950 this percentage had increased to $46 \%$. Coincident with this change was one in the occupational structure of female employment. The clerical sector expanded dramatically from 1890 onward, while female employment in manufacturing had a reduced rate of growth almost every decade from 1890 until 1950 (see Table 4). Most importantly, the timing of changes in labor force participation and occupational structure suggest the operation of labor supply factors. Because off-job training was generally a prerequisite for clerical work, its 


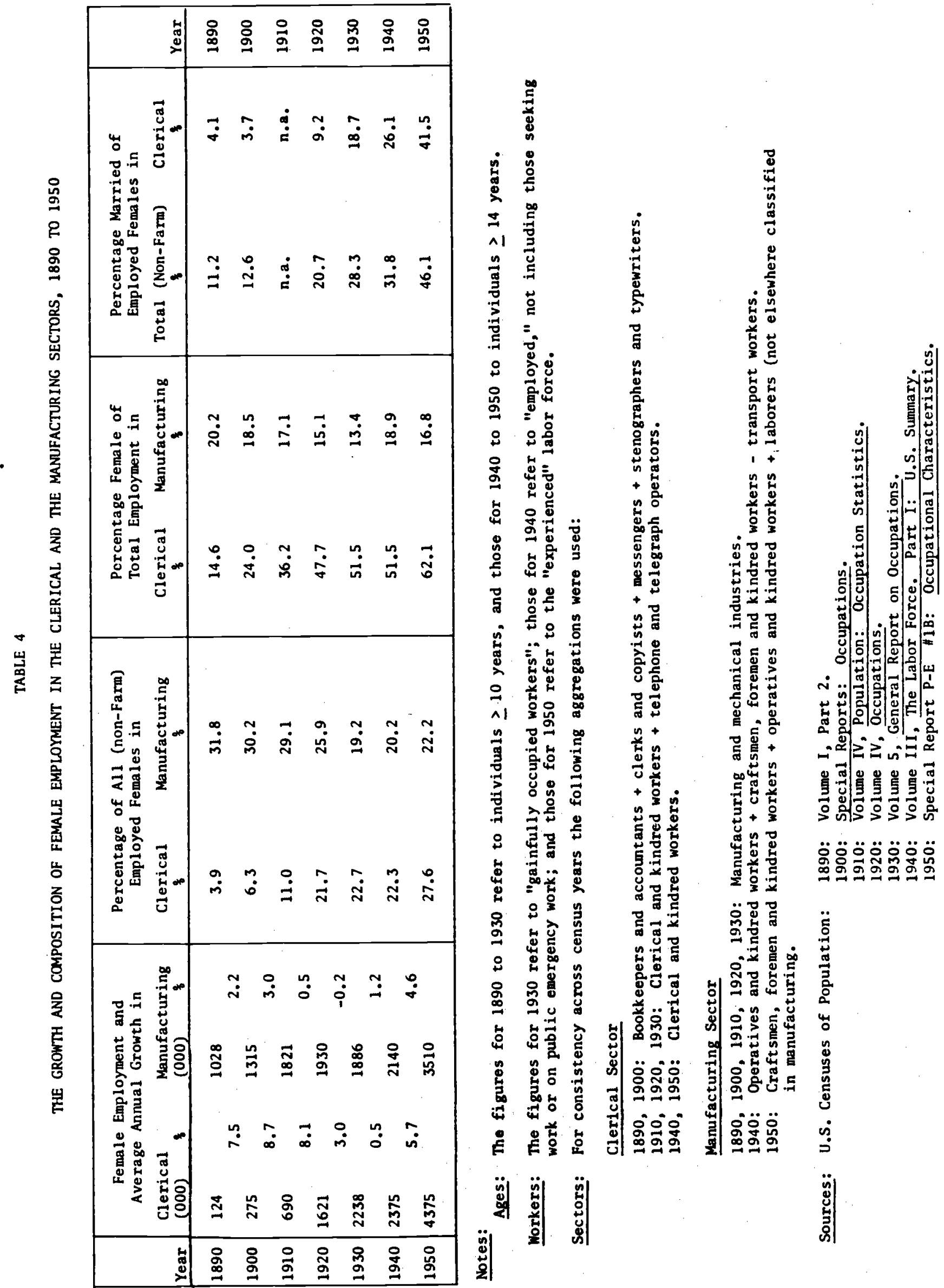


impact on the labor force participation of married women had to have awaited the spread of clerical employment among single women. The increase of married women in clerical employment was, perhaps, the outcome of the continued employment, generally after marriage and child-rearing, of women who had been clerical workers when single. Although the percentage of all clerical workers who were married was lower than that for the non-farm national average for all years from 1890 to 1950 (Table 4), the percentage married in the clerical sector rose far more dramatically, particularly from 1920. The expansion of employment for married women in the clerical sector is even more noteworthy than these data reveal because the rapid growth of this sector in the early period swelled the ranks of single women, as the decline in the percentage married from 1890 to 1900 indicates.

Clerical work was the first numerically important occupation for women, other than teaching, that required some educational commitment and gave, in return, a higher wage and the promise of an earnings profile that made intermittant labor force participation a feasible option. It was the first career for women that had an extensive appeal, in the sense that the term "career" indicates an occupation having a long-run planning horizon. There were various aspects of clerical work that facilitated its rise, some of which are reflected in the estimated earnings function of Section 1. The machinery of clerical work became standardized in the early twentieth century and there was far less specific human capital developed on the job than in the pre-typewriter age. $\underline{15 /}$ Employers no longer had to screen workers with respect to job attachment because training costs were now virtually separate from the job. Clerical work was the beginning of both off-the-job training for women and the standardization of the female work force, and it served, therefore, to increase substitution possibilities among individuals and to raise substitution possibilities in allocating work time over time for individual women. 
During the same decades that clerical work expanded most rapidly, relative wages for clerical workers fell substantially. Paul Douglas' [1930] data indicate that the ratio of wages in clerical work to those in manufacturing $\left(w_{c} / w_{m}\right)$ for men and women combined decreased from 2.21 for the 1890-99 period to 1.74 for 1920-26. 16/ Douglas' data do not distinguish between male and female wage ratios, however various other sources show that the ratio for women decreased more than did the average. One study, using data from the manufacturing censuses of 1890 and 1930, gives a figure of 1.75 for the ratio $\left(w_{c} / w_{m}\right)$ for women in 1890 , decreasing to 1.27 by $1930.17 /$ Although these data are from merely two points in time, independent evidence indicates that both the general trend and the magnitudes are correct, and, in addition, that most of the decrease in the ratio occurred prior to 1920. For example, an extensive survey of bookkeepers, clerks, and stenographers in Ohio from 1914 to 1929 indicates that the ratio $\left(w_{c} / w_{m}\right)$ was 1.36 in 1914 , declining to 1.28 by 1921 , stabilizing there for most of the $1920^{\prime}$ s. Considering only clerical workers in offices gives a ratio of 1.60 declining to 1.33 for the same time period. 18/ Because the clerical wages in the Ohio study are only for bookkeepers, clerks, and stenographers, the overall trend should be more extreme, because typists, who were paid less than average, increased in importance over this period.

Douglas [1930, pp. 366-69] speculated that falling relative wage rates for clerical workers resulted from any one or a combination, of the following three factors. Clerical work could have required less education over time as the nature of the job changed. Secondly, clerical workers in the early twentieth century could have been receiving large quasi-rents which decreased with the expansion of business and commercial vocational schools. Lastly, Douglas noted that his data may have reflected only compositional changes; 
as women became a greater proportion of all clerical workers, the average wage would fall because women's wages were lower than were men's. But because further analysis has shown that wages for women in clerical work declined relative to those for women in manufacturing, this third factor does not appear to be of importance. Douglas' first hypothesis is also thrown into question by the fact that wages in clerical work continued to decline relative to those in manufacturing well past the initial period of replacing the nineteenth century male clerk. There may be some substance to Douglas' second point, about the existence of quasi-rents, although the analysis in Section 3 indicates that a large fraction of the difference in wages can be explained more conventionally.

The remainder of this paper will demonstrate that the difference in wages between female workers in the clerical and manufacturing sectors in 1890 can be explained by the differences in schooling requirements for the two occupations and by, perhaps, a self-selection into clerical work of women who desired to reenter the labor force after marriage. Rising real incomes led to an increase in education and in leisure for daughters. This higher valuation of the time of teenaged girls may have served to decrease the wedge between the initial wage rate in clerical work and that in manufacturing. Reinforcing this effect was the fact that clerical work had far less depreciation with age and little with respect to "home time," and was preferred as the labor force planning horizon of many women became longer. These effects may in turn have been reinforced by other changes such as decreases in the birth rate, the expansion of compulsory education, and increased amenities of office work. 


\section{A Model to Explain the Evolution of Female Occupations}

Over the four decades 1890 to 1930 the average annual rate of increase for female clerical employment was $6.83 \%$, while that for manufacturing was a mere $1.38 \%$. This section will examine how much of the difference in these growth rates may have resulted from increased numbers of young women choosing clerical work over that in manufacturing because of changes in schooling and in life-cycle participation. The large gains in female employment in the clerical sector reflect in part the general expansion of the sector as a whole. But these data are also the result of a shift of women workers from manufacturing to clerical employment. This shift markedly reduced the percentage of manufacturing employees who were women and produced the remarkably swift feminization of the clerical labor force. Demand factors undoubtedly influenced these changes, but there are substantial empirical difficulties in isolating their importance. Instead of attempting to estimate a complete model of this labor market, the coefficients from the earnings functions of Section 1 will be used to explore the possible impact of certain supply side effects.

Assume that the female labor supply schedule to the two sectors is one of constant elasticity, which in rate of change form is given by

$$
\stackrel{*}{Q}^{S}=\stackrel{*}{S}+\varepsilon \stackrel{*}{w}_{m}
$$

where an asterisk $\left(^{*}\right)$ over a variable denotes $\frac{\mathrm{d} \log (\cdot)}{\mathrm{dt}}$, and $\mathrm{w}_{\mathrm{m}}$ is the wage rate in manufacturing. Assume, as well, that the demand schedules for the two sectors are also given by constant elasticity functions which in rate of change form are, for manufacturing

$$
\mathrm{Q}_{\mathrm{m}}^{\mathrm{d}}=\stackrel{*}{\mathrm{M}}-\eta_{\mathrm{m}}{ }^{\mathrm{w}} \mathrm{m}
$$


and for clerical work

$$
\stackrel{*}{Q_{c}^{d}}=\stackrel{*}{\mathrm{C}}-n_{c} w_{m}-n_{c}^{*} k
$$

where $k=\left(w_{c} / w_{m}\right)$. The parameter $k$ is a function of factors such as the training or schooling prerequisites for the occupations (S), the expected lifetime labor force participation of workers (L), and the shape of the earnings functions (E), $k=f(S, L, E)$. A decrease, for example, in schooling costs for clerical work or an increase in expected lifetime labor force participation of workers will decrease $k .19 /$ The total demand in rate of change form is given by a convex combination of (3) and (4)

$$
\stackrel{*}{Q}_{t}^{d}=(1-\alpha) \stackrel{*}{C}+\alpha \stackrel{*}{M}-(1-\alpha) \eta_{c} \stackrel{*}{w}_{m}-\alpha \eta_{m}{ }_{m}^{*}-(1-\alpha) \eta_{c}{ }_{c}^{*}
$$

where $\alpha=\left(Q_{m} / Q_{t}\right)$, the share of total workers in the manufacturing sector. Equilibrium occurs when $(2)=(5)$.

If wages in the two sectors change at the same rate, then $\stackrel{k}{k}=0^{2}$ and the original wedge remains unchanged. But alterations in $S$ or $L$, for example, can cause wages to converge, that is $\mathrm{k}^{\star}<0$, as was the case from 1890 to 1930 . Let $\stackrel{\mathrm{Q}}{\mathrm{c}}_{\mathrm{N}}^{0}$ be the change in clerical employment with ${ }_{\mathrm{k}}^{*}=0$,

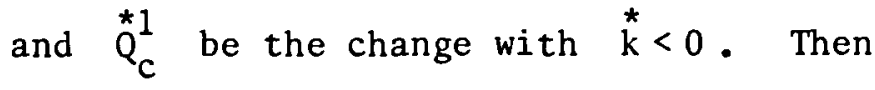

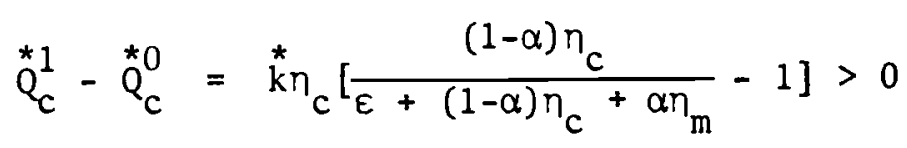

will be the change in clerical employment due to the convergence in average wages in the two sectors, and 


$$
\stackrel{*}{Q}_{m}^{1}-\stackrel{*}{Q}_{m}^{0}=\stackrel{*}{k} \eta_{m}\left[\frac{(1-\alpha) \eta_{c}}{\varepsilon+(1-\alpha) \eta_{c}+\alpha \eta_{m}}\right]<0
$$

will be that for the change in manufacturing employment. Therefore, for given values of $\varepsilon, \eta_{c}$, and $\eta_{m}$ a decrease in $k$ implies an increase in clerical employment relative to that in the manufacturing sector. If all or most of the change in $k$ was a function of the supply side forces stressed above, one can compute their possible impact on relative changes in employment for given values of the elasticities. All that remains to be shown is that a reasonable set of supply side changes can account for most of the change in $k$, and that the earnings functions and life cycle labor force participation in 1890 can account for the initial value of $k$.

It will be assumed that equilibrium in the labor market necessitates the equalization of present discounted net earnings for the two occupations. Individuals choosing between occupations $\mathrm{M}$ (manufacturing) and $\mathrm{C}$ (clerical) will maximize net present discounted value $(P)$ so that at the margin $P_{m}=P_{c}$, that is

$$
\int_{t_{b}}^{\tau_{m}} e^{-r t+M(t)} d t=e^{-r V} \int_{t_{b}+V}^{\tau_{c}} e^{-r t+C(t)} d t
$$

where $M(t)$ and $C(t)$ are earnings functions and $r$ is the discount rate. Labor force participation begins at age $t_{b}$ in manufacturing and at age $\left(t_{b}+V\right)$ in clerical work, where $V$ is years in vocational school. Vocational education is assumed to be costless, except in terms of the opportunity cost of the manufacturing wage. Workers exit the labor force at $\tau_{m}$ and $\tau_{c}$ respectively. 
Simple, but essentially accurate, representations of the earnings functions estimated in Section 1 are, for women in manufacturing,

$$
\begin{array}{ll}
\log Y_{m}=\left[\beta_{m}+0.02 s\right]+0.06 e_{m} & \text { for } e_{m} \leq 15 \\
\log Y_{m}=\left[\beta_{m}+0.02 s\right]+0.9-0.01 e_{m} & \text { for } e_{m}>15
\end{array}
$$

and for women in clerical work,

$$
\log Y_{c}=\left[\beta_{c}+0.03 s+0.05 V\right]+0.034 e_{c}-0.018 H
$$

The incomes in the two occupations are $Y_{m}$ and $Y_{c}, H$ is "home time," and the terms in the brackets are the starting incomes in the two occupations. Both (9) and (10) are linear approximations to the quadratic forms in Tables 2 and 3 to facilitate computations. Equation (9) is piecewise in accordance with the results on married women in manufacturing.

Around the turn of this century, few married women worked for pay outside their homes and most young women entering the labor force could expect to work continuously until marriage. Most industrial censuses at that time indicate that work began at about age 15 in manufacturing, and it seems reasonable to assume here that work lasted for about 10 years. $20 /$ Although 25 is a somewhat late age at marriage, the cohort of single women working in 1890 married later than did any other in American history, and it is possible that work itself delayed marriage for a host of reasons. Assume, as well, that clerical work required three years of vocational schooling but that the choice of occupation did not affect the age at first marriage. $\frac{21 /}{\text { Given (9) and }}$ (10), equation (8) becomes: 


$$
\int_{0}^{10} \exp \left(-r t+5.4+0.06 e_{m_{t}}\right) d t=\exp (-r 3) \int_{0}^{7} \exp \left(-r t+x+0.034 e_{c_{t}}\right) d t
$$

where $\ln (5.4)=\$ 221$ is the initial annual earnings in manufacturing in 1890 , and $x$ is the initial annual earnings in clerical work. 22 If one assumes that the discount rate $r=0.05$, then $x=6.01$; that is starting annual earnings in clerical work would be $\$ 407$. The ratio of beginning earnings in clerical work to those in manufacturing would be 1.84 . Because market earnings are an average of individual earnings, the initial earnings must be used to construct earnings by years of experience and these, in turn, must be weighted by the percentage distribution of years experience in the two sectors. This ratio of the average of annual earnings in each occupation, or the value of $k$, is about 1.65 , a figure that is remarkably close to that of 1.75 , derived from the 1890 manufacturing census. $\frac{23 /}{}$ This wedge between clerical and manufacturing wages is required for a competitive equilibrium in the labor market, given an exogenous set of decisions regarding time spent in the labor market.

Even had the basic structure of the earnings functions remained constant over time, there were several changes on the supply side that could have served to decrease $k$, the ratio of clerical to manufacturing wages for women. Several examples will demonstrate the possible impact on relative wages of these effects. The departure point for these examples will be to hold the starting wage in the manufacturing sector $\left(w_{m}\right)$ at its 1890 level of $\$ 221$, and observe $\left(w_{c} / w_{m}\right)$ respond to supply side changes given the earnings functions and the equilibrium condition of $\mathrm{P}_{\mathrm{m}}=\mathrm{P}_{\mathrm{c}}$. 
The number of female high school graduates increased at an impressive $5.9 \%$ average annually from 1900 to 1920 and at an even greater $6.2 \%$ average annually from 1900 to $1930.24 /$ Although the previous analysis implicitly assumed that the consumption value of education was zero, as incomes rose parents may have regarded their daughters' education to have a positive consumption value. In the absence of information on this value, assume by way of example that in 1930 each year of high school was worth one-third of the earnings per year for a 15 year old in 1890. That is, assume that the consumption value of education was about $\$ 75$ per year in 1930 . The ratio of the beginning wage in clerical work to that in manufacturing in 1890 would then fall from the value of 1.84 derived above to 1.67 , and the average ratio weighted by the probability distributions of years experience in each occupation would fall from 1.67 to 1.49 . If the consumption value were $\$ 100$ per year, the ratio of starting wages would become 1.62 and the weighted average would be 1.45. A related factor that may have affected relative wages and the distribution of women between the two occupations was compulsory school attendance. By the 1920's, every state had a compulsory school attendance law, and states whose laws were passed much earlier revised their upper age limits and added further qualifications. Although most of these laws followed rather than led actual changes in educational attainment, legal restraints could still have had some affect on the choice of occupations for females. $\frac{25 /}{}$ Earnings in manufacturing were somewhat enhanced by primary education, but returns beyond about grade 10 were virtually zero. Delaying entry into the labor force by one year would, however, have increased earnings in manufacturing by about $2.2 \%$ because of increased maturity. Under these assumptionscompulsory attendance to age 16, if enforced, would have served to lower the beginning wage ratio $\left(w_{c} / w_{m}\right)$ from 1.84 to $1.62 . \underline{26 /}$ 
As a final and perhaps most important example, consider that single women could have had a positive expected probability of remaining in the labor force after marriage or of returning after childbearing. Although in 1890 few married women were employed in the labor market, by 1940 to 1950 more than $20 \%$ in the prime ages were. Assume that these $20 \%$ were the same women every year, and therefore that each single woman had a $20 \%$ probability of remaining in the labor force until, say, 50 years old. This effect by itself would serve to decrease the initial ratio $\left(w_{c} / w_{m}\right)$ to about $1.62 .27 /$ of course, if the probability of being in the labor force after marriage were a positive function of labor market experience when single, this ratio would be higher. It should also be added that if parents make education and career decisions for their daughters, the income from work beyond age 25 or so may not have been included in their calculus.

These examples are not meant to show precisely how relative wages in manufacturing and clerical occupations were affected by changes in incomes and institutions from 1890 to 1930 , but to suggest that supply factors of this kind may have been important in the growth of clerical employment. Additional factors could also account for the change in relative wage rates: hours of work may have decreased in the clerical sector relative to those in manufacturing, the amenities of office work may have increased, young women and their parents may have come to believe that office work was of higher social status, and so on. Some combination of these factors could easily account for the entire reduction in the weighted average of $k$, that is the ratio $\left(w_{c} / w_{m}\right)$, from its 1890 level to that of 1930. If one therefore assumes that the entire decrease in $\left(w_{c} / w_{m}\right)$ over this period was a function of such factors, one can calculate their joint influence on employment changes by using equations (5) and (6) and assumed values for the three elasticities. 
The average value of the share of clerical and manufacturing employment in manufacturing or $\alpha=0.69$ for the period 1890 to 1930 , and $\mathrm{k}^{*}=-0.81$. Assume also, by way of example, that $\eta_{c}=\eta_{m}=2$, and $\varepsilon=1$. Then $\left({ }^{*} Q_{c}^{1}-\stackrel{*}{Q}_{c}^{0}\right)=1.285$ and $\left({ }^{*}{ }_{m}^{1}-\stackrel{Q}{0}_{m}^{*}\right)=-0.335$. Therefore, had $k_{k}^{*}=0$, the difference in the average annual rate of change in clerical and manufacturing employment would have been narrowed by about $30 \%$ for the period 1890 to $1930.28 /$ Put another way, had $k_{k}^{*}=0$, the share of the workers in clerical employment $(1-\alpha)$ would have been $39 \%$ by 1930 , although in actuality it was $54 \%$ by that date. The chart below gives results for other reasonable values of the elasticities. For most values, the difference in the growth rates shrinks by one-third or more. These estimates are considerable, particularly since most explanations of the comparative growth of these sectors have stressed differences in demand side shifts.

\begin{tabular}{|c|c|c|c|c|c|c|}
\hline & & $\begin{array}{r}\eta_{c}=\eta_{m}= \\
\varepsilon=1\end{array}$ & $\begin{array}{c}\eta_{c}=\eta_{m}=2 \\
\varepsilon=1\end{array}$ & $\begin{array}{c}n_{c}=2 \eta_{m}=1 \\
\varepsilon=1\end{array}$ & $\begin{array}{c}\eta_{c}=2 \eta_{m}=1 \\
\varepsilon=0\end{array}$ & $\begin{array}{c}\eta_{c}=4 \quad \eta_{m}=2 \\
\varepsilon=2\end{array}$ \\
\hline (1) & $\stackrel{*}{Q}_{c}^{1}-\stackrel{*}{Q}_{c}^{0}$ & 0.684 & 1.285 & 1.185 & 0.853 & 2.370 \\
\hline (2) & $\stackrel{\star}{\mathrm{Q}}_{\mathrm{m}}^{1}-\stackrel{*}{\mathrm{Q}}_{\mathrm{m}}^{0}$ & -0.126 & -0.335 & -0.502 & -0.383 & -0.537 \\
\hline (3) & {$\left[\frac{(1)-(2)}{\left.Q_{c}^{\star}-Q_{m}^{\star}\right]}\right.$} & 0.149 & 0.297 & 0.310 & 0.227 & 0.533 \\
\hline
\end{tabular}

Note: These computations assume $\alpha=0.69, \quad \stackrel{*}{k}=-0.81, \quad \stackrel{\star}{Q}_{c}^{1}=6.83$ and $\stackrel{\star}{Q}_{m}^{1}=1.38$. 


\section{Summary}

By 1950, clerical work had become synonymous with female employment, and its various characteristics made it the perfect example of employment for individuals with intermittant and somewhat abbreviated labor force participation. But earlier in the century, manufacturing employment was of far more importance to women, and the characteristics of its earnings function made it preferable for those who planned to work only when single. I have stressed that in the nineteenth century and early into this one, parents may have severely restricted their daughters' education, thereby limiting occupational choice to work in manufacturing. As real incomes rose and commercial schools spread, young women delayed their entrance into the labor force and opted in greater numbers for clerical work. The rapid rise of clerical work in the early twentieth century may also have been fostered by a greater expectation on the part of these young women to return to the labor force or remain in it after marriage.

The earnings functions estimated with data from the 1888,1907 , and 1940 samples have demonstrated the extreme differences between manufacturing and clerical work. On-the-job learning was an essential part of work in manufacturing, but aging appears to have eventually limited dexterity and therefore earnings. Clerical work, on the other hand, required a minimum amount of off-job training, and earnings were considerably higher for those with education beyond high sćhool. As opposed to work in manufacturing, clerical work enabled the substitution of off-job training for that on-thejob. Time away from clerical employment, and not aging itself, appears to have been an important factor in affecting earnings, but this atrophy of skills or loss in seniority was not of overwhelming importance. Therefore 
as high school education spread and as the labor force participation rates of older women rose, particular characteristics of the clerical occupation gave it an advantage over manufacturing work.

The parameters of the earnings functions estimated in Section 1 were used in Section 3 to predict the decline from 1890 to 1930 in relative wages for clerical and manufacturing work. The supply side changes mentioned were shown to have been of sufficient importance to have generated the large reduction in the ratio of wages, $\left(w_{c} / w_{m}\right)$. Finally, the impact of these changes on the growth of employment in the two sectors was assessed. In conclusion, clerical work is viewed here as offering women a vector of occupational characteristics which became more valuable over time. Its earnings function, which has been more recently viewed as typical of women's employment, replaced one having nearly opposite characteristics in manufacturing, a form of employment which had earlier been viewed as typically female. 


\section{FOOTNOTES}

1. Mincer and Polachek (1974) stress the role of skill depreciation in accounting for differences in earnings between men and women. Polachek (1979) continues this work by estimating atrophy rates for various occupations. However, see Sandell and Shapiro (1978) on these points, as well as the reply by Mincer and Polachek (1978). Zellner (1975) puts more emphasis on the role of training and on the relative flatness of the female earnings function.

2. The Federal Census of Manufactures, 1890, Part I, Table 5, pp.92-114 gives the figure of $35 \%$ but understates pieceworkers in textile mills. The figure of $47 \%$ results from adjusting the manufacturing census information with piece rate data from the Commissioner of Labor, Eleventh Annual Report: 1895-96; Work and Wages of Men, Women and Children (1897).

3. Fourth Annual Report of the Commissioner of Labor, 1888. Working Women in Large Cities (1889) was the product of Carroll Wright's long concern with the conditions of work for women and immigrants. It contains data on 17,427 women in 343 different industries across 22 cities, but because the original schedules do not exist, city-industry cell averages were used instead. The 1907 Study is the Report on Condition of Woman and Child WageEarners in the U.S. in 19 Volumes, Senate Documents Vols. 86-104 (1910/11). Data for married women were taken from New York City (0.572), Philadelphia (0.168), and Chicago (0.104) for the clothing industry, and Massachusetts $(0.097)$ and North Carolina $(0.059)$ for cotton textiles, where the numbers in parentheses indicate percentage of the sample. About $15 \%$ of the married working women in the sample were not employed in these industries but were included in the survey because their children were. The sample for 
single women and girls was taken from all these cities except Philadelphia, in approximately equal proportions.

4. Schooling is measured indirectly in the 1888 Study. For this reason, the average returns to schooling are substantially higher for those data than for the 1907 Study because the 1888 measure implicitly included returns to maturity. But the marginal increment to earnings from a year of education around the mean is about the same in both studies.

5. The literacy variable is not included in the Table 2 regression. When it is entered together with the schooling variable, it substantially reduces the impact of schooling to a marginally significant $1.6 \%$ per year. The schooling squared term then becomes insignificant. It should also be noted that the technique used for converting months of school attended into years of schooling may introduce error, biasing the schooling coefficient towards zerc, if days attended per month varies across individuals or states.

6. The 1907 Study contains individual data for boys under 17 years old and aggregate data for males of all ages. See also Joan Hannon, "The Immigrant in the Promised Land: Human Capital and Ethnic Discrimination in the Michigan Labor Market," unpublished Ph.D. dissertation, University of Wisconsin (1977), Table 3.5 for adult male earnings equations in 1889.

7. This statement leaves open the reasons for the early curtailment of training, whether they be rational, as a function of limited job market attachment, or discriminatory on the part of the labor market, or paternalistic on the part of the family.

8. Only $3 \%$ of the 1907 sample of single women had over 15 years of experience. A more flexible function form using dummy variables for years of experience, also demonstrated that earnings peaked at 15 years experience. 
9. A pooled regression of single and married women using dummy variables for ages indicated that earnings peaked at about age 32 and that married women earned about $10 \%$ less than did single women, correcting for days worked and industrial home work. There was virtually no significant impact from interacting age and marital status. The lower wages for married women independent of age and location of work might indicate a depreciation in skills from time spent at home between work spells but might also reflect their more limited opportunities because of home duties.

10. Manufacturing jobs were extremely taxing physically, and many involved the use of irritating chemicals and dust.

11. A description of the 1930 survey can be found in Women's Bureau Bulletin \#120, Ethel Erickson, "The Employment of Women in Offices," (1934) and that for 1940 in Women's Bureau Bulletin \#188, Parts 1 to 5 (1942), "Office Work in Houston, Los Angeles, Kansas City, Richmond, Philadelphia." The 1940 Philadelphia survey contained data on 12,489 women and 7,988 men.

12. Median salaries rise continuously at about 3 to $4 \%$ per year, with years experience in the present firm, unconditional on education. See Women's Bureau Bulletin \#120, "The Employment of Women in Offices" (1934). It should also be noted that the male earnings profile for clerical work rises far more than does that for women. This finding is similar to that found for contemporary earnings profile for males and females ostensibly in the same set of occupations, (e.g. King 1977).

13. The marginal return to a 9 month year of education in the 1907 manufacturing sample is: 
Year of Education

5

6

7

8
Marginal Return

0.0204

0.0169

0.0134

0.0098

Source: Table 2

It should also be noted that the results from including education as years in school in the 1940 Study gives:

$$
\log Y=\beta^{\prime}+\underset{(0.0244)}{0.068 S}-\frac{0.00155 S^{2}}{(0.00103)}
$$

where $S$ is years in school.

14. Mincer and Polachek (1974) find a $1 \%$ to $1.5 \%$ decline in earnings from home time after the birth of the first child, although their standard errors are quite large. They also find that their measure of atrophy increases substantially with the woman's education. I find essentially the same result. When my measure of home time is interacted with years of schooling, the equation becomes:

$$
\begin{aligned}
& \log Y=B^{\prime \prime}+0.05 H-0.007\left(S^{*} H\right) \\
& (0.0307) \quad(0.0029)
\end{aligned}
$$

where $H=$ years home time and $S=$ years at school. Therefore $\partial \ln Y / \partial H<0$ when $S>7$, and the mean $S=11.5$ for the 1940 Study. It should also be noted that home time in the 1940 Study was positive for single women, who had an average break between work spells of 0.31 years, although it was higher for married women who had on average break of 1.09 years. Almost all of the home time was accumulated between the time these women began all office work and the time they began work for their present firm. 
15. See, for example, Rotella (1977), Chapter IV for a discussion of changes in the nature of clerical work since the late nineteenth century.

16. Douglas' (1930) ciata are fromp. 361, Table 133, column 3 for average annual earnings in ciericai work, and p. 246, Table 88, column 1 for average annual earnings in manufacturing. His clerical category also included salaried personnel.

17. See Rotella (1977), p. 268, Table 6.3. Her 1930 data are derived from estimates by Paul Douglas and Erika Schoenberg made after Douglas computed his combined male-female averages. The raw data are:

\section{Yearly Earnings}

1890

Current \$

Clerical

Manufacturing
463

263
1930

Current \$

1105

868

18. The survey of Ohio clerical workers was reprinted as Women's Bureau Bulletin \#95, Amy G. Maher, "Bookkeepers, Stenographers, and Office Clerks in Ohio 1914 to 1929" (1932). Wages for females in manufacturing during this period are given in National Industrial Conference Board Study Number 229, M. Ada Beney, Wage, Hours, and Employment in the U.S. 1914-1936 (1936). The two series and the ratio aregiven below. Douglas (1930, p. 366) was puzzled by the fact that there were much larger increases in clerical wages in the Maher study than in his. To the extent that the Maher data are biased upward in trend, the decrease in $\left(w_{c} / w_{m}\right)$ would be even greater than that reported below. 
Clerical

Weekly Wages, Median

Current $\$$
Manufacturing

Weekly Earnings, Average

Current \$

1914

$10.52 *(12.40) * *$

7.75

$1.36 *(1.60) * *$

1921

$20.06(20.79)$

15.63

$1.28 \quad(1.33)$

1926

$22.09(22.84)$

17.27

$1.28 \quad(1.32)$

1927

$22.28 \quad(22.93)$

17.37

$1.28 \quad(1.32)$

1928

$22.35 \quad(23.46)$

17.15

$1.30 \quad(1.37)$

1929

$22.40(23.46)$

17.61

$1.27 \quad(1.33)$

* Clerical workers in offices, manufacturing and stores. **

Clerical workers in offices on $1 y$.

Sources: Clerical: Maher, Table 6, p. 13; Manufacturing: Beney, Table 3:25, pp. 48-51.

19. The parameter $\mathrm{k}=\left(\mathrm{w}_{\mathrm{c}} / \mathrm{w}_{\mathrm{m}}\right)=\left(1+\left(\mathrm{w}_{\mathrm{c}}-\mathrm{w}_{\mathrm{m}} / \mathrm{w}_{\mathrm{m}}\right)\right)=\left(1+\left(\mathrm{s} / \mathrm{w}_{\mathrm{m}}\right)\right)$, where, for example, s=schooling costs required for clerical work properly amortized. The model formulated is identical to that used for an excise tax. The wage in manufacturing $\left(w_{m}\right)$ is treated as the "base" wage with the clerical wage as the "base" wage plus the tax. Therefore, $w_{c}$ is not directly entered in (4). It should also be noted that the implicit assumption in the work that follows is the homogeneity of the labor force with respect to the factors affecting k. A more elaborate model would assume that these factors were distributed in some way across the population. A description of a market equilibrium in which heterogeneous workers sort themselves among occupations having different training components can be found in Rosen (1972).

20. It is somewhat difficult to compute total years work experience for women who have completed their working lives from information on the distribution of years experience of the working population. This problem is akin to computing the expectation of 1 ife at birth from information on the age distribution. In the same sense that the expectation of life at birth will depend on the rate of natural increase, the final work life will depend upon the net rate of increase among female manufacturing employees. In 
this way one can use stable population theory to convert a distribution of years work experience into an expected lifetime work experience for an average worker. The data in Working Women in Large Cities $(1889, \mathrm{pp}$. 220-1) on the distribution of years work experience yield an estimate of about 8 years for the expected number of years work. The figure of 10 years is used in the example for convenience, and a lower figure would in fact raise the equilibrium $\left(w_{c} / w_{m}\right)$. See Goldin (1979), for a discussion of this procedure.

21. About $75 \%$ of the women in the Women's Bureau 1930 study of clerical workers had attended high school. Of those clerical workers less than 21 years old in New York City, for example, $35.3 \%$ had graduated from high school. Furthermore, one-third of the women across all ages had some commercial business school training, other than that provided in high school.

22. The starting annual earning of $\$ 221$ is computed from the Table 2 earnings equation for a worker with 5 years schooling, working 280 days per year, living in New York City or Chicago, and beginning work at age 15.

23. This calculation uses the following two work experience distributions:

$\begin{array}{ccc}\begin{array}{c}\text { Years of Work } \\ \text { Experience }\end{array} & \begin{array}{c}\text { Percentage of } \\ \text { Manufacturing }\end{array} & \begin{array}{c}\text { Women Workers } \\ \text { Clerical }\end{array} \\ 0 \leq 1 \text { years } & 0.20 & 0.20 \\ 2 & 0.20 & 0.20 \\ 3 & 0.10 & 0.20 \\ 4 & 0.10 & 0.10 \\ 5 & 0.10 & 0.10 \\ 6 & 0.10 & 0.10 \\ 7 & 0.05 & 0.10 \\ 8 & 0.05 & \\ 9 & 0.05 & \\ 10 & 0.05 & \end{array}$

The distribution for years experience on the job in manufacturing closely approximates that in the 1888 Study (1889, pp. 220-221). That for clerical 
work is a gross approximation to the distribution for work experience among clerical workers in 1930 Philadelphia in Women's Bureau Bulletin $\# 120$ (1934), p. 45 .

24. See Statistical Summary of Education, 1939-40 Biennial Surveys of Education in the U.S. $1938-40,1940-42$ (1947), Vol. II, Chapter 1, p. 19.

25. On the issue of whether the compulsory school attendance laws led or followed change, see G. Stigler Employment and Compensation in Education, National Bureau of Economic Research Occasional Paper \#33 (1950) and W. Landes and L. Solmon (1972), "Compulsory Schooling Legislation: An Economic Analysis of Law and Social Change in the Nineteenth Century," Journal of Economic History, 32:54-91.

26. The problem here is changed somewhat from (2') because discounting is to age 16 and one year increased maturity adds $2.2 \%$ to starting earnings in manufacturing:

$$
\int_{0}^{9} \exp (5.42+.01 t) d t=\exp (-.1) \int_{0}^{7} \exp (x-.016 t) d t .
$$

27. To compute the impact of remaining in the labor force with a $20 \%$ probability, the manufacturing $\mathrm{P}_{\mathrm{m}}$ has three parts and that for clerical work has two:

$$
\begin{aligned}
& \int_{0}^{10} \exp (5.4+.01 t) d t+(.2) \exp (-.5) \int_{0}^{5} \exp (6.0+.01 t) d t \\
& +(.2) \exp (-.75) \int_{0}^{20} \exp (6.3-.06 t) d t=\exp (-.15) \int_{0}^{7} \exp (x-.016 t) d t \\
& +(.2) \exp (-.5) \int_{0}^{25} \exp (x+.238-.016 t) d t .
\end{aligned}
$$


28. The average $\stackrel{\star}{Q}_{c}$ for the four decades 1890 to 1930 was $6.825 \%$ and that for $\stackrel{Q}{m}_{m}$ was $1.375 \%$. Therefore the difference was 5.45 percentage points, which would have been reduced to 3.84 percentage points had ${ }_{k}^{*}=0$, and the percentage reduction is $(1.61 / 5.45)=30 \%$. 


\section{REFERENCES}

P. Douglas (1930), Real Wages in the United States: 1890-1926. Boston.

C. Goldin (1979), "Women in the American Labor Force Experience: Issues, Life-Cycle Participation, and Earnings Functions." Paper presented at the Annual Cliometrics Conference, University of Chicago, June 1979.

A. King (1977), "Is Occupational Segregation the Cause of the Flatter Experience-Earnings Profiles of Women?, " Journal of Human Resources,
12:541-549.

J. Mincer (1974), Schooling, Experience, and Earnings. New York.

J. Mincer and S. Polachek (1978), "An Exchange: The Theory of Human Capital and the Earnings of Women. Women's Earnings Reexamined," Journal of
Human Resources, 13: 118-34.

J. Mincer and S. Polachek (1974), "Family Investments in Human Capital: Earnings of Women," Journal of Political Economy, 82: S76-S108.

S. Polachek (1979), "Occupational Segregation Among Women: Theory, Evidence, and a Prognosis." In C. Lloyd, et al., Eds. Women in the Labor Market.
New York.

S. Rosen (1972), "Learning and Experience in the Labor Market," Journal of Human Resources, $7: 326-342$.

E. Rotella (1977), "Women's Labor Force Participation and the Growth of Clerical Employment in the U.S., 1870-1930." Unpublished Ph.D. dissertation. University of Pennsylvania.

J. Salop and S. Salop (1976), "Self-Selection and Turnover in the Labor Market," Quarterly Journal of Economics, 90: 619-627.

S.H. Sandell and D. Shapiro (1978), "An Exchange: The Theory of Human Capital and the Earnings of Women. A Reexamination of the Evidence," Journal of Human Resources, 13: 103-17.

H. Zellner (1975), "The Determinants of Occupational Segregation." In C. Lloyd, Ed., Sex, Discrimination and the Division of Labor. New York. 